\title{
REKONSTRUKSI KURIKULUM PENDIDIKAN AGAMA ISLAM DI PERGURUAN TINGGI UMUM PASCAPEMERINTAHAN ORDE BARU
}

\author{
Hamka \\ STAIN Datokarama Palu, Jl. Diponegoro No.23 Palu \\ e-mail: hamxaid@gmail.com
}

\begin{abstract}
This research studies Islamic education curriculum reconstruction in High Public Education Institution after the fall of the New Orde. The main focus of this research is to investigate the form of the reconstruction and its relevance to the stakeholders' needs. The issue was studied by using qualitative analysis through library research. The result shows that the paradigm of Islamic education curriculum in 2002 was different from that in the New Orde era (prior to 2000. This affects the changing of teaching material radically where the change becomes more relevant to the stakeholders' needs than the previous curriculum.

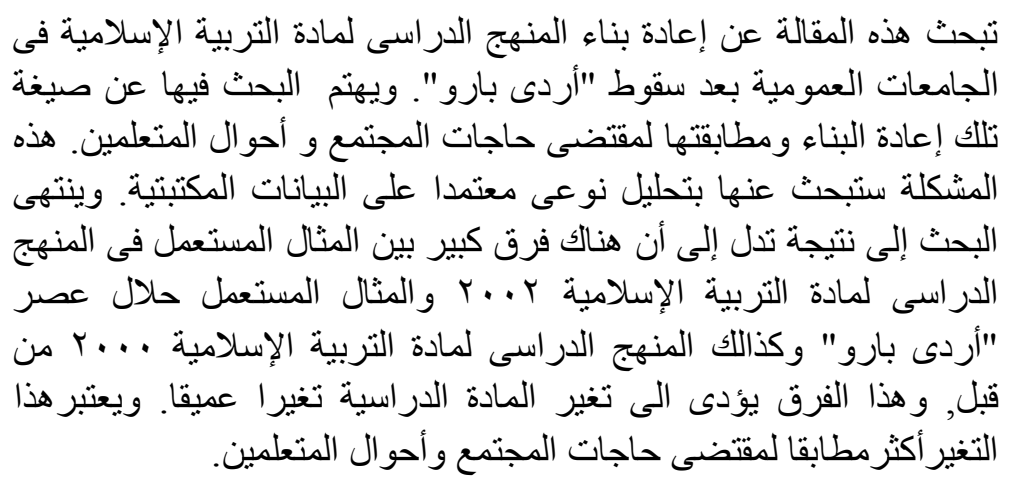

Kata Kunci: rekonstruksi kurikulum, Pendidikan Agama Islam, Orde Baru, Orde Reformasi 


\section{PENDAHULUAN}

Perubahan kurikulum merupakan sebuah keniscayaan sebagai konsekuensi dari perubahan situasi dan kondisi masyarakat tempat berlangsungnya pendidikan. Ellis, dkk. (1986:279), mengklasifikasikan beberapa kategori yang berpengaruh terhadap kurikulum, yaitu: individu-individu yang terlibat dalam komunitas sebuah lembaga pendidikan; kepentingan-kepentingan kelompok yang diorganisasikan secara khusus; kepentingan-kepentingan komersial; para penggagas informasi dan ide-ide baru; perubahan kondisi ekonomi dan masyarakat; organisasi-organisasi profesi dan masyarakat terpelajar; serta evaluasi dan akreditasi eksternal.

Sejalan dengan hal tersebut, perubahan sistem pemerintahan memiliki implikasi yang sangat besar terhadap dunia pendidikan, khususnya dalam hal ini kurikulum. Kebijakan-kebijakan Pemerintah dalam bentuk perundang-undangan, sistem birokrasi dan orientasi politik turut mewarnai corak kurikulum yang ada.

Dalam konteks Indonesia, khususnya pascapemerintahan Orde Baru, banyak perubahan yang terjadi pada tatanan sistem ketatanegaraan kita. Peralihan bentuk pemerintahan dari bentuk sentralistik ke arah desentralistik, perubahan iklim demokrasi, menguatnya isu tentang hak-hak asasi manusia, pengakuan yang lebih tegas terhadap pluralisme budaya, agama dan ras, semua itu berimplikasi terhadap kebijakan Pemerintah di bidang pendidikan.

Dalam hubungan tersebut, perubahan yang terjadi pada aspek sosial, ekonomi dan politik tersebut, perlu dibarengi dengan perubahan kultural, jika tidak maka perubahan tersebut akan melahirkan instabilitas sosial, karena berpijak di atas pondasi yang rapuh (Mun'im DZ, 1998:4).

Salah satu media yang paling tepat dalam upaya perubahan kultural ini adalah pendidikan (Rahman, 2004:8). Dengan demikian, diperlukan langkah-langkah strategis dalam upaya peningkatan mutu pendidikan sejalan dengan tuntutan dan misi gerakan reformasi itu sendiri. Atas dasar inilah maka pada tanggal 7 Nopember 1998 Forum Rektor di Bandung mendeklarasikan perlunya reformasi budaya melalui reformasi Pendidikan (Arifin, 2003:1). Lembaga pendidikan, diharapkan dapat melakukan rekonstruksi pola pikir masyarakat. 
Usaha-usaha Pemerintah dalam meningkatkan mutu pendidikan di era reformasi ini sudah mulai dilakukan, antara lain dalam bentuk peningkatan anggaran pendidikan dan rekonstruksi kurikulum.

Terkait dengan rekonstruksi kurikulum ini, perlu kita cermati secara kritis, apakah perubahan kurikulum tersebut sudah sejalan dengan tuntutan situasi dan kondisi masyarakat, atau hanya bagian dari eporia reformasi, sekedar ingin "tampil beda" dengan model kurikulum Orde Baru.

Salah satu sasaran utama dalam perubahan kurikulum tersebut adalah materi pendidikan agama, khususnya pada Mata Kuliah Pendidikan Agama di Perguruan Tinggi Umum, yang merupakan salah satu bagian dari komponen Mata Kuliah Pembinaan Kepribadian (MKPK).

Hal itu dapat dipahami mengingat bahwa agama merupakan salah satu faktor yang sangat menentukan dalam membentuk kesadaran, cara pandang, dan cara bersikap terhadap realitas. Di samping itu, tragedi kemanusiaan yang terjadi di Ambon dan Poso di masa-masa dini Orde Reformasi, banyak melibatkan term dan simbol keagamaan.

Atas dasar itu, penulis akan mengkaji perubahan kurikulum Pendidikan Agama Islam (PAI) yang terjadi pascapemerintahan Orde Baru, yaitu pada masa pemerintahan Orde Reformasi.

Pada tahun 2000, Pemerintah, melalui Direktur Jenderal Perguruan Tinggi (Dikti) mengeluarkan Surat Keputusan Nomor: 263/DIKTI/KEP/2000 tentang Penyempurnaan Kurikulum Inti Matakuliah Pengembangan Kepribadian Pendidikan Agama pada Perguruan Tinggi di Indonesia. Namun, tidak sampai dua tahun Dikti kembali melakukan perombakan terhadap kurikulum Pendidikan Agama di Perguruan Tinggi Umum melalui Surat Keputusan Nomor: 38/DIKTI/KEP/2002. Dalam kurikulum yang baru ini, tampak jelas terjadinya pergeseran paradigma yang berimplikasi pada perubahan materi yang cukup radikal dari kurikulum sebelumnya. Perubahan radikal yang terjadi dalam waktu yang relatif singkat ini, menarik untuk dicermati. Persoalan inilah yang akan menjadi fokus kajian dalam penelitian ini.

Berdasarkan uraian di atas, rumusan masalah dalam penelitian ini adalah bagaimana bentuk rekonstruksi kurikulum Pendidikan Agama Islam di Perguruan Tinggi Umun pascapemerintahan Orde 
Baru? Dan apakah materi kurikulum PAI tersebut sudah relevan dengan realitas sosial masyarakat Indonesia dan kebutuhan peserta didik?

\section{METODE PENELITIAN}

Penelitian ini bersifat kualitatif, yakni berupaya menghimpun data, mengolah dan menganalisisnya secara kualitatif dan mendefenisikannya secara kualitatif pula (Bachtiar, 1997:21). Penelitian kualitatif umumnya lebih longgar terhadap instrumen pengumpulan data dan lebih fokus pada proses dari pada produk suatu objek penelitian (Muhadjir, 2000:43), sehingga penelitian kualitatif dilakukan berdasarkan pengumpulan data akurat melalui studi kepustakaan (Bodgan \& Taylor, 1975:4).

Data yang digunakan dalam penelitian ini sepenuhnya bersumber dari bahan-bahan kepustakaan. Pengumpulan data dilakukan melalui telaah pustaka yang relevan dengan topik yang sedang dibahas. Sumber data meliputi: buku-buku literatur, dokumen, surat kabar, majalah, jurnal dan web site (internet) yang memuat informasi yang diperlukan. Data yang terkumpul akan diklasifikasikan berdasarkan jenisnya untuk persiapan analisis lebih lanjut.

Data-data yang telah terkumpul dianalisis dengan menggunakan teknik content analysis (analisis isi atau teks), yakni pengkajian terhadap tulisan-tulisan atau buku-buku secara cermat dengan berpijak pada syarat-syarat - sebagaimana yang dikemukakan Noeng Muhadjir (2000:68) - objektif, sistematis dan bersifat generalisasi. Generalisasi yang dimaksud adalah bahwa temuannya mempunyai sumbangan teoritik.

Dalam proses analisis data, digunakan logika induktif dan deduktif secara bervariasi, sebagaimana layaknya dalam penelitian kualitatif pada umumnya.

\section{PEMBAHASAN DAN ANALISIS}

\section{Rekonstruksi Kurikulum PAI di Perguruan Tinggi Umum Pasca pemerintahan Orde Baru}

Pelaksanaan Pendidikan Agama Islam (PAI) di Perguruan Tinggi Umum (PTU) memperoleh landasan yang kokoh sejak dikeluarkan Tap. MPRS No. II Tahun 1960 dan UU. Perguruan Tinggi 
No. 22 Tahun 1961, yang mewajibkan pengajaran mata kuliah agama di perguruan tinggi negeri. Dengan ketetapan tersebut, eksistensi PAI sebagai sarana pembentukan kepribadian mahasiswa semakin kuat.

Sebagai bagian dari kurikulum inti perguruan tinggi, mata kuliah PAI tentu tidak lepas dari kontrol Pemerintah. Kurikulum PAI, dengan demikian, tidak bisa lepas dari kepentingan politik yang sedang berkembang pada saat mana kurikulum itu diberlakukan. Sehingga, perbedaan orientasi, visi dan misi sebuah rezim pemerintahan, akan berimplikasi pada muatan kurikulum PAI itu sendiri.

Pada masa Orde Baru, PAI di Perguruan Tinggi Umum berorientasi murni pada konsep-konsep dasar ajaran Islam normatif. Domain pembahasannya meliputi tiga pilar utama ajaran Islam, yakni akidah, syariah, dan akhlak. Inilah yang dijabarkan dalam kurikulum PAI di PTU.

Apakah kurikulum yang demikian masih tetap dipertahankan di era Reformasi? Berdasarkan hasil penelitian ditemukan bahwa hingga tahun 2002 muatan kurikulum PAI di Perguruan Tinggi Umum masih meneruskan materi yang telah diterapkan pada masa Orde Baru, meskipun mata kuliah ini telah dimasukkan sebagai salah satu kelompok Mata Kuliah Pengembangan Kepribadian (MPK). Namun, sejak tahun 2002, muatan kurikulum PAI di Perguruan Tinggi Umum mengalami perubahan yang cukup drastis.

Pada bagian berikut, akan diuraikan tentang bagaimana perbedaan yang ada antara kurikulum PAI di PTU tahun 2000 dengan kurikulum PAI di PTU tahun 2002.

\section{Perbedaan Paradigma}

Pada dasarnya, penulis tidak menemukan referensi khusus yang membahas paradigma kurikulum PAI, baik kurikulum tahun 2000 maupun kurikulum tahun 2002. Oleh karena itu, dalam membahas masalah ini, penulis melakukan analisis terhadap tujuan dan materi PAI pada kedua kurikulum tersebut untuk menemukan spirit yang dikandungnya dan menjiwai pelaksanaan pembelajaran. Sehingga dengan demikian kita dapat menemukan paradigma pemikiran yang melatarinya. 


\section{Paradigma Kurikulum PAI di PTU Tahun 2000}

Kepmen Diknas Nomor: 232/U/2000, menetapkan Pedoman Penyusunan Kurikulum Pendidikan Tinggi dan Penilaian hasil Belajar Mahasiswa. SK ini menjadi dasar penyelenggaraan program studi di Perguruan Tinggi yang terdiri atas (a) kurikulum inti, dan (b) kurikulum intruksional. Kurikulum Inti Pendidikan Tinggi terdiri atas (a) kelompok Matakuliah Pengembangan Kepribadian (MPK); (b) kelompok Matakulaih Keahlian Berkarya (MKB); Kelompok Matakuliah Berkehidupan Bermasyarakat (MBB). Mata kuliah Pendidikan Agama termasuk dalam kelompok MPK seperti halnya PPKN.

Seiring dengan itu, dalam rumusan penyempurnaan kurikulum mata kuliah PAI di Perguruan Tinggi Umum, dijelaskan:

Pendidikan Agama Islam di Perguruan Tinggi bertujuan untuk membantu terbinanya mahasiswa yang beriman dan bertakwa kepada Tuhan Yang Maha Esa, berbudi pekerti luhur, berfikir filosofis, bersikap rasional dan dinamis, berpandangan luas, ikut serta dalam kerjasama antar umat beragama dalam rangka pengembangan dan pemanfaatan ilmu dan teknologi serta seni untuk kepentingan manusia dan nasional (Nomor: 263/DIKTI/KEP/2000).

Rumusan di atas tampak berbeda dengan rumusan yang terdapat dalam kurikulum PAI di masa Orde Baru. Sebagaimana dideskripsikan dalam GBPP PAI bahwa mata kuliah PAI bertujuan:

Mengkaji dan memberi pemahaman tetang hakikat manusia yang membutuhkan panduan hidup, baik secara individu maupun sosial dalam rangka mencapai kebahagiaan dunia dan akhirat. Dengan memahami dirinya dan alam semesta yang telah diberi aturan oleh Penciptanya, aturan itulah yang disebut ayat kauniyah dan tanziliyah. Ayat tanziliyah inilah yang dirinci pada bahasan akidah, syari'ah, akhlak dan sejarah Islam. Penekanan utama ada pada aplikasi ajaran tersebut pada tingkah laku keseharian, baik yang bersumber dari AlQur'an maupun dari sunnah Rasulullah S.A.W (GBPP PAI dalam http://bima.ipb.ac.id).

Meski demikian pada aspek materi, penyempurnaan kurikulum PAI tahun 2000 tidak berbeda sama sekali dengan materi kurikulum PAI di masa Orde Baru. Titik tekan materi PAI lebih berorientasi pada konsep-konsep keislaman tradisional, yang berkisar pada akidah, syariah (dalam arti fikih) dan akhlak. Di samping itu, dalam sejumlah 
hal tidak ditemukan adanya perbedaan signifikan antara materi kurikulum PAI pada Perguruan Tinggi dengan kurikulum mata pelajaran Agama Islam pada Tingkat Dasar dan Menengah (Balitbang Depdiknas dalam http://puspendik.com dan Supriyadi dalam http://digilib.itb.ac.id/gdl). Meskipun ada perkembangan materi pada tingkat perguruan tinggi, perkembangan tersebut lebih bersifat vertikal yakni materi yang telah dipelajari pada tingkat sebelumnya lebih dipertajam, dengan pendekatan rasional filosofis. Akan tetapi tidak ada perkembangan yang bersifat horizontal, dalam memperluas wilayah kajian pada isu-isu kontemporer.

Dengan kondisi yang demikian, tidak dapat dihindari dominannya pendekatan doktriner dalam proses pembelajaran PAI tersebut. Ajaran agama sebagai sesuatu yang harus diimani, diterima tanpa kritik, dan merupakan barang jadi yang siap pakai.

Paradigma kurikulum Pendidikan Agama Islam tahun 2000 tersebut masih merupakan kelanjutan dari paradigma kurikulum Orde Baru. Wilayah keislaman terkesan begitu sempit, seputar rukun iman dan rukun Islam ditambah dengan seperangkat aturan tata krama dalam pergaulan sehari-hari. Dengan demikian, konsep keagamaan cenderung bersifat statis karena sekedar melanjutkan tradisi teologis dari para ulama terdahulu.

Mungkinkah paradigma yang demikian ini sengaja ditanamkan penguasa pada masa Orde Baru untuk meredam kekuatan oposisi yang bisa lahir dari pemahaman keagamaan yang dinamis. Kecurigaan seperti ini tentu cukup beralasan, mengingat kurikulum merupakan produk dari penguasa, dan bahwa umat Islam dalam sejarah Indonesia merupakan salah satu kekuatan yang sangat diperhitungkan.

\section{Paradigma Kurikulum PAI di PTU Tahun 2002}

Perubahan iklim politik di Indonesia pada masa-masa awal Orde Reformasi, konflik sosial di berbagai daerah, serta lahirnya semacam fobia terhadap segala hal yang berhubungan dengan Orde Baru, semua itu berimplikasi terhadap dunia pendidikan, termasuk dalam hal ini kurikulum PAI di PTU.

Oleh karena itu, jika pada konsep penyempurnaan kurikulum PAI tahun 2000 paradigma yang digunakan masih merupakan warisan Orde Baru maka pada kurikulum 2002 paradigmanya sangat berbeda. Mata kuliah PAI di PTU tidak lagi berbicara tentang rukun iman dan 
rukun Islam belaka (bahkan untuk materi ini porsinya sangat minim), melainkan lebih dominan mengkaji tentang Islam dalam kaitannya dengan isu-isu kontemporer, seperti, hak-hak asasi manusia, demokrasi, hukum, sistem politik, masyarakat madani dan toleransi antar umat beragama.

Dalam Surat Keputusan Dikti Nomor 38 Tahun 2002 dinyatakan bahwa: "Visi Matakuliah Kelompok Pengembagan Kepribadian (MPK) di Perguruan Tinggi menjadi sumber nilai dan pedoman bagi penyelenggaraan program studi dalam mengantar mahasiswa mengembangkan kepribadiannya (Dikti, 2002: pasal 1)."

Misi utamanya adalah membantu mahasiswa agar mampu mewujudkan nilai dasar agama dan kebudayaan serta kesadaran berbangsa dan bernegara dalam menerapkan ilmu pengetahuan, teknologi dan seni yang dikuasainya dengan rasa tanggung jawab kemanusiaan (Dikti, 2002: pasal 2).

Selanjutnya, kompetensi dasar yang ditargetkan adalah menguasai kemampuan berpikir, bersikap rasional dan dinamis, berpandangan luas sebagai manusia intelektual (Dikti, 2002: pasal 3). Sedangkan, untuk tujuan PAI di Perguruan Tinggi Umum, adalah:

Mengantarkan mahasiswa sebagai modal (kapital) intelektual melaksanakan proses belajar sepanjang hayat untuk menjadi ilmuwan yang berkepribadian dewasa yang menjunjung tinggi kemanusiaan dan kehidupan (Dikti, 2002, pasal 3 ayat 1).

Dalam rumusan di atas, tidak lagi ditemukan term "iman" dan "takwa" sebagaimana yang ditekankan pada kurikulum sebelumnya. Sehingga jika rumusan tersebut dibaca tanpa melihat judulnya, tentu tidak ada kesan yang mencerminkan bahwa itu merupakan rumusan tujuan mata kuliah PAI.

Namun, dalam materi instruksional PAI yang diterbitkan oleh Dipertais Departemen Agama RI pada tahun 2004 ditegaskan bahwa kompetensi PAI adalah mengantar mahasiswa untuk (1) mengusai ajaran agama Islam dan mampu menjadikannya sebagai sumber nilai dan pedoman serta landasan berpikir dan berperilaku dalam menerapkan ilmu dan profesi yang dikuasainya; (2) menjadi "intellectual capital" yang beriman dan bertakwa kepada Allah swt, berakhlak mulia dan berkepribadian Islami (Dikti Depag, 2004: vii). 
Paradigma yang mendasari kurikulum PAI tahun 2002 ini adalah paradigma yang melihat agama sebagai sesuatu yang dinamis dan hidup dalam setiap aspek kehidupan. Agama bukanlah sekedar seperangkat aturan normatif untuk memenuhi kebutuhan spritualitas manusia. Agama adalah sebuah pandangan hidup, dan dengan demikian, agama memiliki pengaruh yang sangat kuat dalam membentuk cara pandang terhadap realitas kehidupan. Dan karena realitas selalu dalam proses perubahan maka konsep keagamaan haruslah bersifat dinamis dalam merespon kondisi kekinian.

Krisis multidimensi yang melanda Indonesia di era reformasi, menghendaki lahirnya perubahan paradigma dalam berbangsa dan bernegara. Penghargaan terhadap hak-hak asasi manusia, penegakan demokrasi, supremasi hukum, dan pemberdayaan masyarakat sipil, merupakan agenda penting reformasi yang mesti "dibudidayakan" melalui pendidikan.

Di samping itu, konflik sosial yang terjadi di berbagai daerah di tanah air, menuntut peninjauan ulang terhadap cara pandang kita terhadap pluralisme agama, budaya, suku dan etnik. Yang dibutuhkan adalah kesepahaman dalam perbedaan dan bukannya menciptakan keseragaman dalam keragaman sebagaimana yang dilakukan di masa Orde Baru.

Berangkat dari paradigma baru ini, muncullah konsep pendidikan agama yang berwawasan kultural, seperti yang ditawarkan Zakiyuddin Baidhawy (2007) dalam bukunya Pendidikan Agama Berwawasan Multikultural. Konsep ini menawarkan pendekatan dialogis untuk menanamkan kesadaran hidup bersama dalam keragaman dan perbedaan, dibangun atas semangat kesetaraan dan kesederajatan, saling percaya, saling memahami, menghargai persamaan, perbedaaan, keunikan dan independensi. Model pendidikan semacam ini memberikan konstruk baru yang bebas dari prasangka dan stereotipe mengenai agama orang lain, bebas dari bias dan diskriminasi atas nama apapun, baik itu agama, jender, ras, warna kulit, kebudayaan, maupun kelas sosial.

Zakiyuddin Baidhawy (2007:45-46), menegaskan bahwa:

Sebagai risalah profetik, Islam pada intinya adalah seruan pada semua umat manusia, termasuk mereka para penganut agama-agama menuju satu cita-cita bersama kesatuan kemanusiaan (united of mankind) 
tanpa membedakan ras, warna kulit, etnik, kebudayaan, dan agama. Pesan kesatuan ini secara tegas disinyalir dalam Alquran: "Katakanlah wahai semua penganut agama (dan kebudayaan), bergegaslah menuju dialog dan perjumpaan multikultural (kalimatun sawa') antara kami dengan kalian." Kalimatun sawa' bukan hanya mengakui pluralitas kehidupan, ia adalah manifesto dan gerakan yang mendorong kemajemukan (plurality) dan keragaman (diversity) sebagai inti kehidupan dan mengukuhkan pandangan bahwa semua kelompok multikultral diperlakukan setara (equality) dan sama martabatnya (dignity).

Lebih lanjut beliau menegaskan bahwa klaim berlebihan tentang kebenaran absolut kelompok keagamaan sendiri, dan klaim kesesatan atas kelompok-kelompok agama lain, berpotensi meningkatkan sentiment permusuhan antar umat beragama. Penganjur-pengajur dengan pendekatan teologis dogmatis semacam ini dapat dengan mudah membawa dan memicu konflik dan kekerasan pada level pengikut. Dan anehnya, semua mengatasnamakan Tuhan (Baidhawy, 2007:48).

Pendekatan multikultural dalam pendidikan agama mendapat dukungan luas dari kalangan akademis, sebagai sebuah pendekatan yang tepat dalam merespon konteks sosial masyarakat Indonesia yang pluralis.

Demikianlah, bila dibandingkan dengan kurikulum tahun 2000, dapat dilihat bahwa telah terjadi pergeseran paradigma yang sangat tajam pada kurikulum PAI di Perguruan Tinggi Umum tahun 2002.

Kepentingan politik, tentu saja memiliki andil dalam hal ini. Penulis beranggapan bahwa pembaruan kurikulum ini, di samping diperuntukkan untuk menyukseskan agenda reformasi dalam hal penegakan HAM, demokratisasi, dan pemberdayaan masyarakat sipil, serta memupuk kesadaran akan pluralisme, juga untuk meredam lahirnya kelompok-kelompok radikal yang berbasiskan Islam. Seperti diketahui, isu terorisme yang ditujukan kepada kelompok-kelompok Islam "radikal" di Indonesia, merupakan salah satu masalah yang mendapat perhatian ekstra serius dari pemeritah Indonesia di era reformasi. Bahkan kelompok-kelompok Islam "radikal" di Indonesia mendapat "pengawasan khusus" dari dunia international. 


\section{Perbedaan Materi Kurikulum}

Materi PAI di PTU pada Kurikulum Tahun 2000

Pada penyempurnaan kurikulum Pendidikan Agama Islam di Perguruan Tinggi Umum, sesuai dengan Keputusan Dikti Nomor:263 tahun 2000, materi pembahasannya terdiri dari 9 pokok bahasan dengan beberapa sub bahasan masing-masing, sebagaimana yang terlihat pada tabel 1 .

Materi yang disajikan masih terkonsentrasi pada tiga domain utama ajaran Islam, yakni Akidah, syari'at dan akhlak. Tampak jelas adanya pengulangan dari materi Pendidikan Agama Islam pada tingkat dasar dan menengah, sehingga pada dasarnya materi PAI di tingkat perguruan tinggi dapat dianggap sebagai pematangan dari materi mata pelajaran Pendidikan Agama Islam yang telah dipelajari sebelumnya pada tingkat SLTA ke bawah. Perbedaan yang tampak hanya pada aspek penghayatan terhadap nilai-nilai (hikmah) yang terkandung dalam ajaran Islam itu, seperti hikmah salat, puasa, zakat, dan haji. Sedangkan yang terkait dengan akidah masih berkisar pada persoalan rukun iman.

Meskipun persoalan HAM telah disinggung dalam materi kuruikulum PAI tahun 2000 tersebut, namun tidak dikaji secara mendalam, melainkan sekedar pelengkap dalam materi pembahasan tentang akhlak dan takwa.

Dengan memperhatikan pokok bahasan dan sub pokok bahasan pada tabel 1 di bawah ini, dapat dipahami bahwa mata kuliah PAI dalam kurikulum tahun 2000 lebih banyak menggunakan pendekatan teologis doktriner.

Tabel 1. Materi Pokok Pendidikan Agama Islam di Perguruan Tinggi Umum Berdasarkan SK. Dikti No. 263 tahun 2000

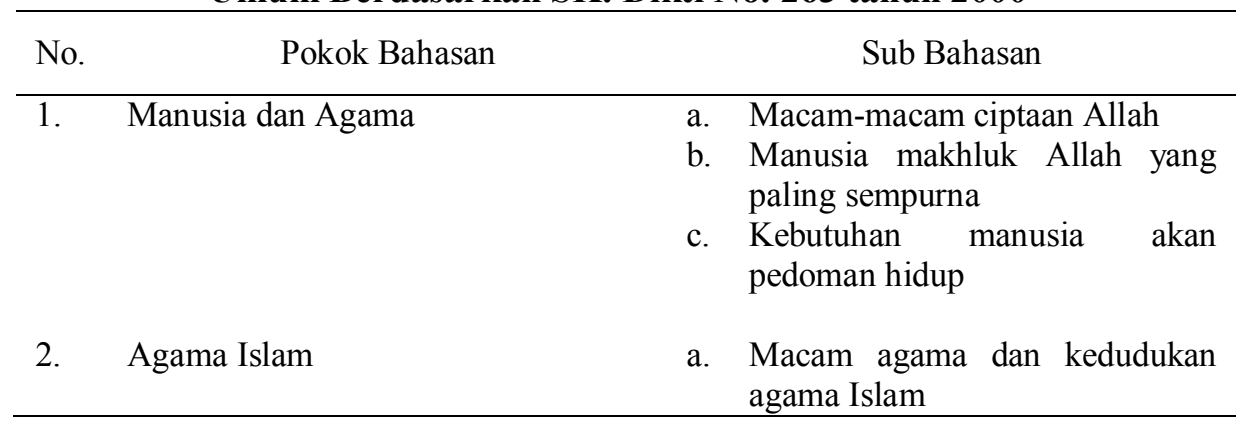


Jurnal Hunafa, Vol. 6, No.1, April 2009: 69-92

\begin{tabular}{lll}
\hline No. & \multicolumn{2}{c}{ Sub Bahasan } \\
\hline & bokok Bahasan & $\begin{array}{l}\text { Peranan agama Islam dalam } \\
\text { menentramkan batin dan } \\
\text { membawa kedamaian }\end{array}$
\end{tabular}

3. Sumber Ajaran Islam

4. Kerangka Dasar Ajaran Islam

5. Akidah

6. Syariat, Ibadah dan Muamalah

7. Akhlak a. Sistematika sumber ajaran Islam

b. Penggunaan akal sebagai sumber ajaran Islam

a. Akidah, syariat dan akhlak

b. Agama Islam dan Ilmu-ilmu keislaman

c. Filsafat, tasawuf dan pembaharuan dalam Islam

a. Arti dan ruang lingkup akidah

b. Kemaha-esaan Allah

c. Kiamat, hukum alam dan akhirat

d. Peranan malaikat dan makhluk gaib lainnya serta pengaruhnya terhadap manusia

e. Tugas dan peranan nabi dan rasul

f. Fungsi kitab suci yang dibawa rasul bagi umatnya

g. Pengertian kada dan kadar

a. Pengertian dan ruang lingkup syariat Islam

b. Pengertian, tujuan, kedudukan dan hikmah ibadah dalam Islam

c. Arti salat dan hikmahnya bagi kehidupan

d. Pelaksanaan dan hikmah puasa

e. Pelaksanaan dan hikmah zakat

f. Pelaksanaan dan hikmah haji

g. Muamalah dalam Islam

h. Kewarisan dalam Islam

i. Prinsip kerja sama umat beragama

a. Pengertian dan ruang lingkup akhlak yang menghormati HAM, serta perbedaannya dengan moral dan etika 
Hamka, Rekonstruksi Kurikulum...

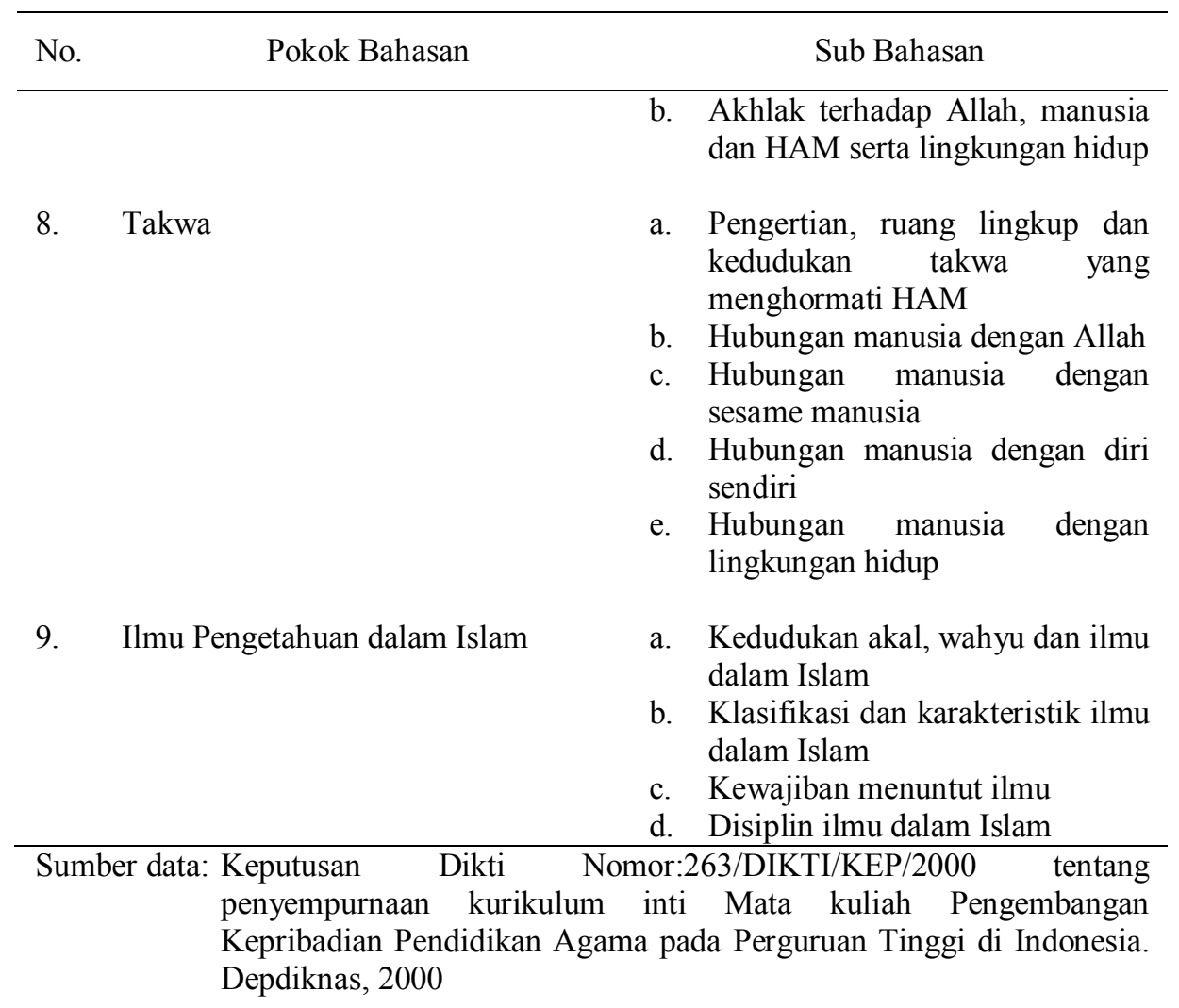

Materi PAI di PTU pada Kurikulum Tahun 2002

Berbeda dengan kurikulum PAI sebelumnya, dalam kurikulum PAI tahun 2002 materi yang disajikan lebih responsif terhadap isu-isu kontemporer yang berkembang di tengah masyarakat, khususnya di era reformasi. Untuk lebih jelasnya, berikut ini dipaparkan pokok bahasan dan sub bahasan dalam mata kuliah PAI di PTU sesuai yang diamanahkan dalam Keputusan. Dikti No. 38 tahun 2002, tentang rambu-rambu pelaksanaan kelompok mata kuliah Pengembangan Kepribadian di Perguruan Tinggi, pada pasal 4 dijelaskan tentang dasar substansi kajian mata kuliah Pendidikan agama, meliputi:

- Tuhan Yang Maha Esa dan Ketuhanan

- Keimanan dan ketakwaan

- Filsafat ketuhanan (teologi)

- Manusia 
- Hakekat dan martabat manusia

- Tanggung jawab manusia

- Moral

- Implementasi iman dan takwa dalam kehidupan sehari-hari

- Ilmu pengetahuan, teknologi dan seni

- Iman, ilmu, amal sebagai kesatuan

- Kewajiban menuntut ilmu dan mengamalkan ilmu

- Tanggung jawab ilmuwan terhadap alam dan lingkungan

- Kerukunan antar umat beragama

- Agama merupakan rahmat bagi semua

- Hakekat kebersamaan dalam pluralitas beragama

- Masyarakat

- Peran umat beragama dalam mewujudkan masyarakat madani yang sejahtera

- Tanggung jawab umat beragama dalam mewujudkan hak-hak asasi manusia (HAM) dan demokrasi

- Budaya

- Tanggung jawab umat beragama dalam mewujudkan cara berpikir kritis, bekerja keras dan bersifat fair.

- Politik

- Konstribusi agama dalam kehidupan politik berbangsa dan bernegara

- Hukum

- Menumbuhkan kesadaran untuk taat hokum Tuhan

- Peran agama dalam perumusan dan penegakan hokum yang adil

○ Fungsi profetik agama dalam hukum (Dikti, 2002).

Dasar substansi pokok bahasan tersebut selanjutnya dijabarkan ke dalam pokok bahasan dalam mata kuliah Pendidikan Agama untuk masing-masing agama, artinya, Pendidikan Agama di Perguruan Tinggi memiliki topik yang sama pada masing-masing agama, topik itulah yang akan diterjemahkan berdasarkan konsep atau persepsi dari setiap agama.

Sehubungan dengan hal tersebut, pada tahun 2004 Dipertais Depag menerbitkan buku pedoman Materi Instruksional Pendidikan Agama Islam di Perguruan Tinggi Umum. Dalam buku ini terdapat 9 materi pokok yang selanjutnya diuraikan dalam beberapa sub bahasan, sebagaimana yang dipaparkan pada tabel 2 berikut ini: 
Tabel 2. Materi Pokok Pendidikan Agama Islam di Perguruan Tinggi Umum Berdasarkan SK. Dikti No. 38 tahun 2002

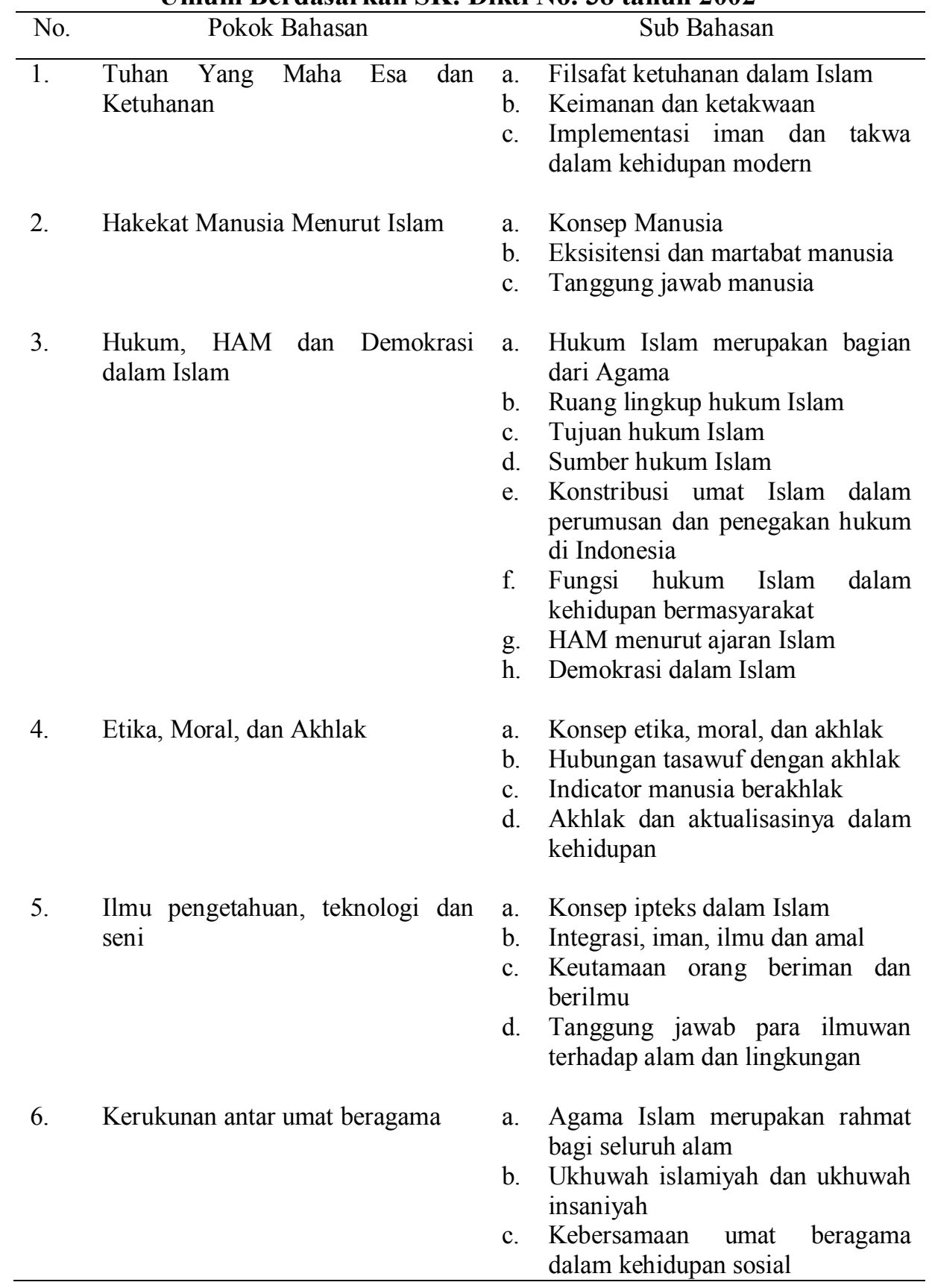


Jurnal Hunafa, Vol. 6, No.1, April 2009: 69-92

\begin{tabular}{|c|c|c|}
\hline No. & Pokok Bahasan & Sub Bahasan \\
\hline 7. & $\begin{array}{l}\text { Masyarakat Madani } \\
\text { Kesejahteraan Umat }\end{array}$ & $\begin{array}{ll}\text { a. } & \text { Konsep masyarakat madani } \\
\text { b. Peran umat Islam dalam } \\
\text { mewujudkan masyarakat madani } \\
\text { c. Sistem ekonomi Islam dan } \\
\text { kesejahteraan umat } \\
\text { d. Manajemen zakat } \\
\text { e. } \\
\text { Manajemen wakaf }\end{array}$ \\
\hline 8. & Kebudayaan Islam & $\begin{array}{l}\text { a. Definisi kebudayaan Islam } \\
\text { b. Sejarah intelektual Islam } \\
\text { c. Nilai-nilai Islam dalam budaya } \\
\text { Indonesia } \\
\text { d. Masjid sebagai pusat peradaban } \\
\text { Islam }\end{array}$ \\
\hline 9. & Sistem Politik Islam & $\begin{array}{l}\text { a. Pengertian politik Islam } \\
\text { b. Nilai-nilai dasar sistem politik } \\
\text { dalam Alquran } \\
\text { c. Ruang lingkup pembahasan } \\
\text { siyâsah dusturiyyah }\end{array}$ \\
\hline
\end{tabular}

Uraian materi PAI di atas menunjukkan wawasan yang lebih luas sebagai sebuah pandangan hidup yang dinamis dan selalu berdialog dengan konteks sosial. Tidak lagi mengulang-ulang materi pelajaran SLTA ke bawah yang terbatas pada persoalan-persoalan rukun iman dan rukun Islam, sebagaimana halnya pada kurikulum tahun 2000.

Pendidikan Agama Islam di era sekarang, sebagaimana diungkap al-Faruqi (1968:45), dihadapkan kepada perubahan yang mendasar, terutama mempersiapkan peserta didik yang nantinya akan berintegrasi dengan masyarakat yang berasal dari berbagai macam latar belakang budaya dan agama. Untuk mendapatkan hasil maksimal dari sebuah proses pendidikan agama, ada dua hal sebagai "pekerjaan rumah (PR)", terutama pendidik agama Islam, yakni: para pendidik tersebut sudah saatnya membutuhkan pengertian yang mendalam dan harus merasa peka terhadap isu-isu pemahaman keagamaan yang sedang berkembang dalam masyarakat umum. Selanjutnya, para pendidik ini harus bisa membantu peserta didik untuk menyadari pentingnya memahami budaya yang bermacammacam dalam masyarakat, khususnya di bidang keagamaan. 
Jika tidak demikian, tampaknya lembaga pendidikan sulit berpartisipasi dalam menengahi model-model pemahaman Islam radikal yang sering dituduh sebagai penyulut munculnya ketidaknyamanan dalam masyarakat beragama. Lembaga-lembaga pendidikan, terutama di masa akan datang, harus bisa memproduksi sarjana Islam yang berpikiran moderat untuk mewadahi berbagai macam pemahaman yang cenderung radikal itu. Untuk mengujudkan itu, seluruh unsur sistem pendidikan Islam, khususnya pembelajaran agama Islam, sebaiknya ditelaah kembali (Sangkot, 2007 dalam http://sangkot.wordpress.com).

Berbagai upaya untuk mengembangkan materi PAI di Perguruan Tinggi Umum saat ini terus digalakkan dengan mengacu pada spirit yang terkandung dalam kurikulum 2002 tersebut. Salah satu di antaranya adalah Pendidikan Agama Islam yang berwawasan multikultural.

\section{Relevansi Kurikulum PAI Tahun 2002 dengan Kebutuhan Masyarakat}

Pembahasan tentang relevansi kurikulum PAI dengan kebutuhan masyarakat, tidaklah dimaksudkan dengan meminta tanggapan langsung dari warga masyarakat, melainkan dengan melihat relevansinya dengan tuntutan sistuasi dan kondisi sosial, politik dan budaya masyarakat Indoneisa, khususnya di era Reformasi.

Benturan berbagai ide yang melibatkan elemen-elemen Islam sejak bergulirnya era reformasi muncul dalam berbagai aspek sosial, keagamaan dan poltik. Dalam hal ini yang mengemuka antara lain menanggapi soal perempuan jadi presiden, pemberlakuan syariat Islam, keabsahan demokrasi, pluralisme beragama, makna jihad, hingga persoalan-persoalan politik dan teologi yang lain. Proses dinamis dalam perkembangan kontemporer Islam di Indonesia dan perwajahan baru radikalisme dalam gerakan Islam yang semakin meningkat tentu saja menarik untuk dicermati secara seksama (Mubarak, 2008:114-115).

Baju radikalisme dan fundamentalisme yang dipakai atas nama Islam oleh kelompok tertentu menjadi "boomerang" bagi umat Islam sendiri. Di Indonesia, kedua aliran itu telah menggejala baik secara terang-terangan maupun tersembunyi. Fenomena demikian 
menyebabkan kekhawatiran berbagai kalangan masyarakat, sebab alur pemikiran semacam itu telah merasuki anak-anak, pelajar dan mahasiswa.

Dalam situs GP Anshor dikemukakan bahwa: Momok ekstrem kanan yang dulu begitu diwaspadai oleh Orde Baru kini hilang dari kamus politik Indonesia. Kelompok Islam radikal memang berhasil "ditumpas" rezim Orde Baru pada tahun 1980-an. Namun, dalam waktu hampir bersamaan generasi di bawahnya diam-diam membangun jaringan di kampus-kampus (http://www.gp-anshor.org).

Kemudian disusul dengan munculnya kelompok-kelompok pengajian kampus pada akhir 1980-an yang terkenal dengan sebutan "kelompok tarbiyah," melalui kelompok inilah transmisi Islam radikal di Timur Tengah berkembang di Indonesia, khususnya di kampuskampus perguruan tinggi umum (http://www.gp-anshor.org).

Setelah era reformasi mereka lebih berani tampil ke permukaan secara terang-terangan. Bagi sebagian kalangan, kemunculannya dianggap mengkhawatirkan, bukan semata-mata karena perbedaan ideologis, tetapi lantaran sebagian di antaranya menggunakan caracara kekerasan memperjuangkan aspirasinya. Kekerasan di sini tak hanya dalam arti fisik, tetapi juga kekerasan wacana yang terekspresi melalui kecenderungan mereka yang dengan mudah mengeluarkan fatwa murtad, kafir, syirik, dan semacamnya bahkan kepada sesama Muslim (http://www.gp-anshor.org).

Kita sadari bahwa Indonesia adalah negara plural yang terdiri dari beragam suku, ras, agama, budaya yang berbeda-beda tetapi tetap satu Indonesia. Pluralisme yang menjadi ciri bangsa dan Negara Indonesia ini, semestinya diimbangi dengan demokratisasi yang kuat sehinggaa tidak menimbulkan gejolak baru yang berkembang. Islam sebagai agama yang rah $\square$ matan li al-âlamîn seyogyanya dimaknai oleh penganutnya dengan penuh keramahan, kedamaian, dan kasih sayang. Bukan sebaliknya, seolah-olah Islam menjadi sesuatu yang mengerikan, menyeramkan, dan menakutkan bagi umat lain, sehingga performen keseluruhan umat Islam pun turut terpengaruh. Arogansi, kepongahan, serta kecongkakan yang mementingkan keinginan kelompoknya masing-masing adalah benih dari sebuah bentuk radikalisme. Karena itu, di era global sekarang ini wajah seram semacam itu, tak boleh lagi tumbuh berkembang. 
Berdasarkan hasil survey yang dilakukan oleh the Wahid Institute tentang persepsi umat Islam Indonesia terhadap agama Islam dan isu terorisme, diperoleh data bahwa sebanyak $2,7 \%$ dari responden percaya bahwa terorisme dibolehkan dalam ajaran Islam. Pertanyaan-pertanyaan yang diajukan pada pokoknya berpijak pada asumsi-asumsi pluralism. Dan meskipun angka 2,7\% itu kecil, tetapi untuk jumlah penduduk yang mencapai sekitar 130 juta maka angka tersebut cukup besar (JBP dan Yuli Ahmada, dalam http://rumahkiri.net).

Oleh karena itu, teramat penting untuk memberikan pemahaman keislaman yang berwawasan luas kepada para generasi muda sehingga tidak mudah terjebak dalam radikalisme yang dilatari oleh sempitnya wawasan keagamaan yang dimilikinya. Tampaknya, Inilah salah satu kebutuhan yang coba dijawab dalam kurikulum PAI tahun 2002 tersebut.

Dengan melihat setting sosial masyarakat Indonesia di masa awal reformasi, materi yang ditawarkan dalam kurikulum PAI tahun 2002 tersebut sudah relevan. Masyarakat Indonesia di era reformasi ini membutuhkan pencerahan pemikiran keagamaan yang lebih luas, terutama menyangkut isu-isu krusial yang terjadi dalam negeri. Pemahaman yang benar tentang hak asasi manusia, demokrasi, masyarakat madani, pluralisme agama, ras, budaya, etnik, dan bahasa.

Perubahan iklim politik di Indonesia ke arah yang lebih demokratis juga memberi peluang pada umat Islam untuk menyuarakan aspirasinya termasuk ide-ide yang bernuansa Islami. Oleh karena itu, hubungan Islam dan politik perlu mendapat perhatian dalam kurikulum PAI, khususnya pada level Perguruan Tinggi.

Singkatnya, perubahan paradigma dan materi kurikulum PAI di Perguruan Tinggi tahun 2002, pada dasarnya merupakan refleksi dari kebutuhan masyarakat muslim Indonesia di era reformasi ini. Kurikulum ini juga memungkinkan pendidikan untuk mengantar mahasiswa memahami wacana-wacana global dalam perspektif Islam. Dengan demikian, Pendidikan Agama Islam diharapkan dapat menumbuhkan cara pandang Islami dalam melihat realitas, sehingga Islam menjadi agama yang hidup dinamis dalam berdialog dengan segala bentuk perubahan konteks sosio kultural historis, tanpa harus kehilangan jati diri dan orisinalitasnya. Bila kita meyakini Islam sebagai agama yang terakhir dari Allah swt., kita pun harus yakin 
bahwa wawasan keislaman akan mampu merespon kebutuhan masyarakat sepanjang zaman, Islam tidak mungkin statis karena realitas terus mengalami perubahan.

\section{Relevansi Kurikulum PAI Tahun 2002 dengan Kebutuhan Peserta Didik}

Istilah kebutuhan peserta didik di sini bukan diartikan sebagai kebutuhan yang bersumber dari keinginan peserta didik secara personal, melainkan kebutuhan berdasarkan asumsi dengan melihat korelasi antara kurikulum PAI di tingkat Perguruan Tinggi dengan kurikulum PAI di tingkat dasar dan menengah. Sebagai ilustrasi, jika seorang anak didik telah mempelajari tata cara berwudu maka kebutuhan selanjutnya adalah materi tentang salat atau tayammum, bukannya tata cara berwudhu lagi, terlepas dari kenyataan bahwa di antara siswa masih ada yang belum menguasai tata cara berwudhu. Demikian juga, jika siswa belum pernah mempelajari tata cara berwuhu lalu materi yang diberikan langsung membahas tata cara salat maka pada dasarnya materi tersebut tidak sesuai dengan kebutuhannya, meskipun mereka ingin mempelajarinya dan secara riil memang membutuhkannya.

Dengan demikian, kebutuhan peserta didik yang dimaksud di sini adalah kebutuhan dari sudut pandang paedagogik. Secara sederhana, kebutuhan yang dimaksud adalah korelasi antara materi yang akan dipelajari dengan materi yang telah dipelajari pada level sebelumnya.

Pada kurikulum PAI untuk tingkat SLTA tahun 2004 ruang lingkup materinya berfokus pada aspek: Alquran/hadis, keimanan, syari'ah, akhlak, tarikh. Sedangkan kompetensi dasar umum yang harus dicapai meliputi (1) beriman kepada Allah swt. dan lima rukun iman yang lain dengan mengetahui fungsi dan hikmahnya serta terefleksi dalam sikap, perilaku, dan akhlak peserta didik dalam dimensi vertikal maupun horizontal; (2) dapat membaca, menulis, dan memahami ayat-ayat Alquran serta mengetahui hukum bacaannya dan mampu mengimplementasikan dalam kehidupan sehari-hari; (3) mampu beribadah dengan baik sesuai dengan tuntunan syariat Islam, baik ibadah wajib maupun ibadah sunnah; (4) dapat meneladani sifat, sikap, dan kepribadian Rasulullah, sahabat, dan tabiin serta mampu mengambil hikmah dari sejarah perkembangan Islam untuk 
kepentingan hidup sehari-hari masa kini dan masa depan; (5) mampu mengamalkan sistem mu'amalat Islam dalam tata kehidupan bermasyarakat, berbangsa, dan bernegara (Pusat Kurikulum Balitbang Depdiknas, 2008: 9-10).

Berdasarkan paparan di atas, dapat diketahui bahwa materi Pendidikan Agama Islam pada tingkat SLTA telah membahas secara rinci pokok-pokok ajaran Islam dengan tiga domain utama, yaitu akidah, syariat, dan akhlak. Oleh karena itu, seyogyanya materi-materi tersebut tidak lagi berulang pada tingkat Perguruan Tinggi.

Bahkan, di samping materi-materi pokok yang diajarkan dalam kelas, PAI di tingkat SLTA juga ditunjang dengan kegiatan ekstrakurikuler. Dalam pedoman kurikulum PAI untuk SLTA ditegaskan bahwa: kegiatan ekstrakurikuler PAI dapat mendukung kegiatan intrakurikuler, misalnya melalui kegiatan pesantren kilat, imtaq Ramadhan, peringatan hari-hari besar Islam, bakti sosial, salat Jumat, tahun baru Islam, lomba baca tulis Alquran (BTA), dan lain-lain (Pusat Kurikulum Balitbang Depdiknas, 2008:16).

Dengan demikian, kebutuhan peserta didik pada tingkat Perguruan Tinggi bukan lagi mengarah kepada persoalan-persoalan yang telah mereka pelajari di bangku SLTA, tetapi perluasan wawasan keislaman terutama yang berkaitan dengan isu-isu kontemporer, baik yang berkembang di dalam negeri maupun dalam dunia international.

Bila materi PAI di tingkat Perguruan Tinggi hanya mengulang materi yang ada pada level sebelumnya, implikasi yang ditimbukan antara lain:

- Mahasiswa merasa jenuh dan menganggap remeh mata kuliah PAI. Kesan yang muncul kemudian adalah mata kuliah ini hanyalah pelengkap SKS dan tidak memiliki nilai tambah terhadap pengetahuan mereka.

- Wawasan keagamaan mahasiswa menjadi sempit, agama dipahami sekedar sebagai media pensucian diri, pemuasan spritual, untuk memperoleh keselamatan di akhirat.

- Sempitnya wawasan keagamaan mahasiswa tersebut menjadi sasaran empuk bagi propaganda kelompok radikal Islam, yang pada akhirnya melahirkan kelompok-kelompok radikal Islam di Perguruan Tinggi. Perlu dicatat bahwa kelompok semacam ini, 
seperti disinyalir oleh Mubarak (2008:114-115), lebih banyak berkembang di lembaga Perguruan Tinggi Umum.

- Pemahaman keagamaan mahasiswa terlepas dari kehidupan riil serta kondisi sosio kultural masyarakat, sehingga hal ini berpotensi melahirkan pandangan sekuler.

Untuk menghindari implikasi negatif di atas, materi PAI pada Perguruan Tinggi Umum harus dihadirkan dengan wawasan yang luas dan kontekstual. Pada level inilah sebenarnya Islam dihadirkan dengan dimensi yang dinamis, moderat, dan peka terhadap pluralitas serta menonjolkan karakteristiknya sebagai rah $\square$ matan li al 'alamîn. Jika hal ini masih dianggap "tabu" dibicarakan pada level Perguruan Tinggi, lalu pada level mana hal itu dianggap layak. Apakah hanya terbatas pada Perguruan Tinggi Agama Islam? Jika demikian cara berpikir kita, pada dasarnya kita sudah tersekulerkan secara tidak sadar.

Mata kuliah PAI di Perguruan Tinggi semestinya mampu membentuk wawasan keislaman yang pada akhirnya melahirkan pandangan dunia yang islami. Inilah yang dibutuhkan anak didik dari proses pembelajaran mata kuliah PAI.

Atas dasar pemikiran tersebut, materi kurikulum PAI di Perguruan Tinggi Umum tahun 2002, sudah cukup relevan dengan kebutuhan peserta didik, terutama bila dibandingkan dengan kurikulum PAI tahun 2000 sebelumnya.

Dari segi koherensinya dengan kurikulum PAI pada tingkat SLTA, kurikulum PAI pada PTU tahun 2002 tersebut sudah koheren dan sesuai dengan kebutuhan peserta didik. Pada tingkat SLTA mereka digembleng dengan prinsip-prinsip dasar ajaran Islam, yang meliputi akidah, syariah, dan akhlak. Sedangkan pada tingkat Perguruan Tinggi mereka dibekali dengan perluasan wawasan keislaman dalam merespon persoalan-persoalan kontemporer, seperti: hak asasi manusia (HAM), demokrasi, pluralisme, masyarakat madani, sistem politik, manajemen zakat dan wakaf, toleransi antar umat beragama, dan sebagainya.

Dalam melihat persoalan-persoalan kontemporer tersebut, tentu tidak berarti bahwa mahasiswa digiring untuk mengekor pada ide-ide Barat. Mengkaji HAM bukan berarti sepakat dengan pelaksanaan HAM yang dipraktekkan oleh Barat, tetapi memungkinkan untuk mengkritisinya dalam perspektif Islam. Begitu juga, membahas demokrasi bukan berarti mereka dipaksakan untuk menerima konsep 
demokrasi Barat secara mentah-mentah, sebaliknya mereka diperkenalkan pada konsep demokrasi dalam perspektif Islam yang menempatkan Tuhan sebagai pemegang kedaulatan tertinggi dan rakyat (manusia) sebagai pemegang mandat kekhalifahan.

Dengan cara yang demikian, para sarjana muslim di masa depan, diharapkan memiliki komitmen keislaman yang kuat dengan memahami kesempurnaan Islam sebagai agama yang tidak hanya berurusan dengan keselamatan akhirat tetapi juga berkewajiban menciptakan kemakmuran di bumi (dunia).

\section{PENUTUP}

Berdasarkan uraian sebelumnya, dapat ditarik kesimpulan bahwa telah terjadi pergeseran paradigma pada kurikulum PAI di perguruan tinggi umum pasca pemerintahan Orde Baru, khususnya pada kurikulum PAI tahun 2002. Paradigma yang dikembangkan melihat Islam sebagai sebuah cara pandang yang bersifat dinamis dan responsif terhadap kekinian.

Pergeseran paradigma ini berimplikasi pada perubahan materi pembelajaran PAI di perguruan tinggi umum yang tidak lagi mengulang-ulang materi yang ada pada tingkat dasar dan menengah, melainkan lebih akomodatif terhadap isu-isu kontemporer seperti HAM, demokrasi, pluralisme dan masyarakat madani.

Dengan demikian, materi PAI dalam kurikulum tahun 2002 cukup relevan dengan kebutuhan masyarakat Indonesia di era reformasi ini, di samping juga sejalan dengan kebutuhan peserta didik pada tingkat perguruan tinggi yang memerlukan wawasan keislaman yang lebih luas dan dinamis.

\section{DAFTAR PUSTAKA}

al-Faruqi, 1968. dalam Jurnal of Ecumenical Studies, volume 5, No. 1, Winter.

Arifin, Anwar. 2003. Memahami Paradigma Baru Pendidikan Nasional dalam Undang-undang Sisdiknas. Cet. ke-3. Jakarta: Ditjen Kelembagaan Agama Islam Depag.

Bachtiar, Wardi. 1997. Metodologi Penelitian Ilmu Dakwah. Cet.ke-1. Jakarta: Logos.

Baidhawy, Zakiyuddin. 2007. Pendidikan Agama Berwawasan Multikultural. Jakarta: Erlangga

Bodgan, Robert dan Steven J. Taylor. 1975. Instrduction to Qualitative Research Method. New York John Wiley \& Sons. 
Direktorat Perguruan Tinggi Agama Islam Departemen Agama RI, 2004. Materi Instruksional Pendidikan Agama Islam di Perguruan Tinggi Umum. Jakarta: Direktorat Perguruan Tinggi Agama Islam Departemen Agama RI.

Ellis, Arthur K., et al., 1986. Introduction to the Foundation of Education. New Jersey: Prentice-Hall, Engliwood Cliffs.

Garis-garis Besar Program Pengajaran Pendidikan Agama Islam dalam http://bima.ipb.ac.id/ tpb-ipb/gbpp/gbpp-agamaislam. diakses 11 Oktober 2008

Keputusan Dikti Nomor: 263/DIKTI/KEP/2000 tentang penyempurnaan kurikulum inti Mata kuliah Pengembangan Kepribadian Pendidikan Agama pada Perguruan Tinggi di Indonesia. Depdiknas, 2000

Keputusan Direktur Jenderal Pendidikan Tinggi Departemen Pendidikan Nasional RI, Nomor: 38/DIKTI/KEP/2002 Rambu-rambu Pelaksanaan Kelompok Mata Kuliah Pengembangan Kepribadian di Perguruan Tinggi.

Mubarak, Zaki. 2008. Geneologi Islam Radikal di Indonesia, Gerakan, Pemikiran dan Prospek Demokrasi. Jakarta: LP3ES.

Muhadjir, Noeng. 2000. Metodologi Penelitian Kualitatif. Edisi ke-4, Cet. ke-1. Yogyakarta: Rake Sarasin.

Mun'im DZ, Abdul. 28 September, 1998. Reformasi Budaya untuk Reformasi Total. Kompas.

Pusat Kurikulum Departemen Pendidikan Nasional, Badan Penelitian dan Pengembangan. 2004. "Kurikulum 2004: Standar Kompetensi Mata Pelajaran Pendidikan Agama Islam Sekolah Menengah Atas dan Madrasah Aliyah" dalam http://elcom.umy.ac.id., diakses 11 Oktober 2008

Pusat Penilaian Pendidikan BALITBANG Depdiknas. 2005. "Panduan Materi Pendidikan Agama Islam SD/MI-Kurikulum 1994" dalam http:/puspendik.com/ebtanas/ujian2005/PDF/ PAMSD94ISL05. diakses 11 Oktober 2008

Rahman, Darmawan Mas'ud, 2004. "Nilai Budaya dan Konflik: Sebuah Kajian Singkat Diamati dari Sudut Budaya Kekinian", Makalah disampaikan dalam seminar sehari STAIN Datokarama Palu, 20 Desember.

Sangkot. 2007. "Landasan Normatif Pendidikan Agama Islam Multikultural" dalam http://sangkot.wordpress.com/2007/ 11/09/landasan-normatif-pendidikan-agama-islam-multikultural, diakses 10 Oktober 2008

Supriyadi. 2003. "Studi Tentang Karakteristik Kurikulum Pendidikan Agama Islam Sekolah Menengah Umum Tahun 1994" dalam http://digilib.itb.ac.id/gdl.php?mod=browse\&op=read\&id=jiptummgdl-s1-2003-supriyadi9-262\&q=Islam, diakses 11 Oktober 2008 